\title{
Perceived Risk/Security and Consumer Involvement with Electronic Payments in Nigeria: A Discriminant Analysis.
}

\author{
Titus Chukwuemezie Okeke PhD. \\ Department of Marketing Nnamdi Azikiwe University, Awka, Nigeria.
}

\begin{abstract}
This paper presents a classification of e-payment customers in Nigeria on the basis of high and low involvement and to find out the perceived risk/security factors that are dominant in the classification. Based on an empirical survey of e-banking customers from different segments in Nigeria with questionnaire as the instrument for data collection; the authors employed discriminant analysis to ascertain which of the perceived risk/security factors of psychological risk, quality risk, time-loss risk, financial risk, physical risk and security that are dominant in classifying e-banking customers on the basis of high and low involvement. The results show that the ATM/debit/credit cards command high involvement followed by telephone/GSM banking, while others like master/visa cards, internet banking, among others are less preferred. Time-loss risk and security are the most dominant in classifying e-banking customers though these two factors are the dominant the discriminant structure matrix show that the seven factors are important as they all contribute to the classification. The findings of this study has implications for banks and policy makers toward ensuring that e-banking services are secure and that the risks associated e-banking transactions are minimised. The study also has implications for further studies in consumer involvement and consumer behaviour.
\end{abstract}

Keywords: e-payments, cashless economy, perceived risk, security, banking reforms, Nigeria, consumer involvement.

\section{Introduction}

The Central Bank of Nigeria (CBN) in late 2011 initiated the cashless policy that with effect from the late 2012, daily cumulative free cash withdrawals and lodgements by individuals and corporate customers do not exceed a maximum ceiling of $\$ 150,000$ and $\$ 1$ million, respectively. This was later reviewed before the take-off the programme to $\$ 500,000$ and $\$ 3$ million respectively. This move according to the apex bank is expected to reduce the amount of currency outside the banking system by discouraging the use of cash in financial transactions. With the pilot scheme that commenced in Lagos late 2012 and gradually spreading to other states, the CBN has engaged in creating awareness on the necessity for a cashless economy. What informed the new policy is that the Nigerian economy is too heavily cash-oriented in transactions of goods and services, which CBN notes is not in line with global trends. CBN estimates that about $65 \%$ of the cash in circulation in the Nigerian economy is outside of the banking system, thus limiting the impact of the bank's efforts at price and economic stabilisation. Also, the huge volume of cash transactions impose tremendous costs to the banking sector and, consequently, the customer, in terms of cash management, frequent printing of currency notes, currency sorting and cash movements (CBN, 2012). As the volume of cash in circulation grows, so does the cost of cash management to the financial system which is estimated at 192 billion. There is also the risks involved in keeping or moving large amounts of cash, namely the high incidences of robberies and burglaries and the public's propensity to abuse and mishandle currency notes. As a major play in the world economy and a leader on the African continent, Nigeria should be at the forefront of economic modernisation. In 2006, the Federal government through the CBN initiated payment system vision 2020, a subset of the financial system strategy (FSS) 2020 which unambiguously states the vision of facilitating economic activities by providing safe and efficient mechanisms for making and receiving payment with minimum risks to the Central Banks, payment service providers and end users, extending the availability and usage to all sectors and geographies and conforming to internationally acceptable regulatory, technical and operational standard (FRN 2007). FSS 2020 is part of the overall vision 2020 programme of the Federal Government which aims at graduating the economy to top 20 in the world by year 2020. According to the CBN/FRN, the Nigeria financial system will be modelled to provide safety in order to mitigate the perception usually associated with emerging economies. Also the rate of growth of the economy will be measured by clearly defined parameters using the key emerging markets as initial benchmarks (FRN 2007). The total value of e-payments in Nigeria as at 2011 stood at 1670.5 Billion with ATM accounting for $88.9 \%$ of that amount. However, with the adoption of ebanking by all the banks in Nigeria and its attendant advantages, the volume of cash in circulation as at end of December-2011 is 1565.76 Billion (CBN 2011) has continued to increase pre-and-post consolidation exercise. In its 2012 half-year financial sector stability report, the CBN notes that the expansion of the electronic means of payment in the economy portends risk to banks, merchants and the general public; and also poses challenges 
to the payments system. The apex bank notes further: "especially critical is the issue of identity theft and electronic fraud, and their impact on the payments system" (CBN-FSR 2012, p.27). The aim of this paper is to classify bank customers in Nigeria on the basis of involvement with e-payments with respect to perceived risk/security variables using discriminant analysis. Consumer involvement is defined as the perceived personal importance or interest attached to the acquisition, consumption, and disposition of a good, service, or idea (in Hynes, and Lo, 2005). It is a theoretical construct that draws on the cognitive styles of consumers when trying to explain consumer behaviour. One obvious advantage of e-payments from the banks' view point is that it offers better branding and better responsiveness to the market (Salehi and Alipour, 2010). In light of this, consumer involvement can be useful in consumer marketing as it can provide a basis for a motivational force that can explain various outcomes of consumer behaviour, such as the number and type of choice criteria, extensiveness of information search, length of decision process and brand switching (Knox et al, 1994). With the cashless policy, the CBN aims to achieve an environment where a higher and increasing proportion of transactions are carried out through cheques and e-payments, in line with global trends. This portends risk and poses security challenges and consumer involvement with this new trend necessitates empirical investigation.

\subsection{Types of Consumer Involvement}

\section{Literature Review}

The concept of involvement was originally investigated in the field of social psychology by Sherif and Cantril (1947) who viewed it as the relation between ego and an object. Later Sherif, et. al. (1965) referred to it as the centrality of beliefs involved with an individual. The concept of involvement was first employed in studies on attitude change and used in social judgment theory which postulates that an audiences' response to a persuasive message is determined by two factors acting together: prior attitude toward; and involvement (Sherif and Hovland 1961; Zaltman and Wallendorf, 1983). From a consumer behaviour point of view, involvement is defined as the heightened state of awareness that motivates consumers to seek out, attend to, and think about product information prior to purchase (Beckman et. al. 1997). It is also seen as a person's perceived relevance of the object based on their inherent needs, values, and interests (in Solomon 2005). Involvement is the psychological outcome of motivation and is the perceived level of personal importance or interest evoked by a stimulus within a given situation (Arnould, et. al. 2004). Consumers experience involvement as cognitive perceptions of importance and interest and affective feelings of arousal (Peter and Olson 2002). The degree of consumer involvement in a specific product category is widely recognised as a major variable relevant to advertising and other marketing strategies (Ray 1973). Depending on their level of involvement, individual consumers differ in the extent of their decision process and their search for information. In addition, consumers may be passive or active when they receive advertising communication depending on their involvement level (Laurent and Kapferer, 1985). As a result, the concept of involvement has played an increasingly important role in explaining consumption and risk associated with it. It may also affect the level of brand loyalty (Robertson 1976), brand discrimination, the amount of comparison between products (Zaichkowshy 1985), the amount and role of information searching (Robertson 1976), how advertising is processed (Krugman 1965), and which elements within an advertisement are responded to (Petty et al, 1983). Various types of involvement have been described, defined and measured stemming from different application of the term "involvement". The literature on involvement shows that there are three major domains of involvement, which are commonly used by researchers: advertising domain; product class domain and purchasing decision domain (Zaichkowsky, 1986). The literature further shows that these three domains are related in the sense of their personal relevance. Four types of consumer involvement have been recognised. First, cognitive involvement: this includes heightened thinking and processing of information about the goal object. Adverts that provide a detailed enumeration of information about a product or websites that induce comprehensive brand comparisons appeal to cognitive involvement (Arnould et. al. 2004). This component of involvement consists of the individual beliefs and knowledge about the object/product - whether good or bad, necessary or unnecessary, useful or useless and so on (Achumba 2006). The cognitive component is based on reason and is related to knowledge and experience; however for most attitude objects, we have a number of beliefs the configuration of which represents the cognitive component/type. In the traditional hierarchy of effects, beliefs (defined by the determinant attributes) influence the overall evaluation of the brand which then influences choice. Two, affective involvement: include heightened feeling and emotional energy. According to Achumba (2006) affective component is what the individual feels about the object -whether it is pleasant or unpleasant etc. Adverts that encourage people to experience the feelings and sensations associated with products like ATM or other e-payments stimulate affective involvement. Third, Enduring involvement: this type of involvement relates to consumer's interest in an offering or activity over a long period of time. According to Berkman et. al. (1997) enduring involvement reflects feelings experienced toward a product category that are persistent over time and across different situations. 
Fourth, situational involvement: this type of involvement is characterized by a temporary interest in the goal object. It refers to the emotional feelings a consumer experiences in a particular situation when he or she thinks about a particular product. It is specific to a product or situation and is temporary (Berkman et al 1997). Thus while situational involvement is triggered by a special situation or a consumer response in any situation related to pre-purchase, purchase, and post - purchase situation; enduring involvement comes from and is part of the consumer and endures. Berkman et al emphasize the distinction between situational and enduring involvement stating that the difference is important because when marketers measure involvement they examine the extent to which it can be induced by the product or selling situation.

\subsection{Levels of Consumer Involvement}

The type of information processing that will occur depends on consumers' level of involvement. Academics, researchers and practitioners in marketing recognize two levels of consumer involvement. These are high and low/medium involvement: High involvement consumers may have strongly held beliefs about brands and perceive great differences between brands in a product class. They often have a favourable or preferred brand and are brand loyal. But may also use brand experimentation as way of learning about new alternatives for future purchase decisions (Ratchford 2001). High involvement consumers are willing to spend more time and money and visit a greater number of stores (Arnould et al 2004). Thus, with high involvement, attention is increased and more importance is attached to the stimulus object. Arnould et al adds that with high involvement memory is also enhanced. They maintain that since high involvement motivates consumers to spend time and effort to avoid post purchase dissatisfaction, these consumers generally report higher satisfaction and less negative disconfirmation with the product they purchase. Second: low involvement consumers are not active information seekers and take comparisons among brands. Low involvements consumers are willing to try unfamiliar brands without a full search for information and without forming a strong preference first (Arnould et al 2004). They don't see a lot of difference between brands and view them as reasonable substitutes for one another. That is, they don't have special preferences for a particular brand, and brand loyalty is not very strong. High involvement consumers are information processors and constitute an active advertising audience. Hall (2003) argues however that this depends on execution:

... whether advertising stimulates low or high involvement processing is only one dimension of the problem, and it is likely not the most important one. What is more important is whether advertising stimulates an emotional response from the consumer. Emotional engagement at some level is a prerequisite for behavioural change cognition processing of information is secondary to the underlying emotional and behavioural effects. (Hall, 2003. p.38).

There are two sets of consequences that should be clear from the above (Lawson 2001). First: in low involvement situations, it is accepted that there may be little or no evaluation of the product before purchase. Attitudes that are formed are weakly held and are primarily based on experience derived from consumption. Second: low involvement is often reflected in consumers proceeding directly from need recognition to purchase with no information search or evaluation of alternatives.

High involvement consumers are also said to be brand loyal. However, literature points to behaviour loyalty which describes customers who are loyal because of inertia rather than because of any strong feeling of the brand. This type of behavioural (or spurious) loyalty is prevalent in the financial services because there is lack of differentiation in the market place (in Howcroft et. al. 2007). The two more commonly used multi-item scales are those of Laurent and Kapferer (1985) and Zaichkowsky (1985). Zaichkowsky's (1985) scale (PII) treats involvement as a uni-dimensional construct while Laurent and Kapferer's (1985) CIP scale treats involvement as a multidimensional. Aldlaigan and Buttle (2001) used both PII and CIP scales to measure involvement on financial services and concluded that whilst PII shows better reliability CIP can yield more information since it measure five dimensions of involvement and highlight the relative importance of some dimensions over others. Their empirical findings show that the scales indicate different levels of involvement in the eight financial services studied; hence they concluded that certain dimension of the involvement in each of the two scales: PII and CIP were irrelevant in the financial services and that a new customized scale could be of value. The present study relies on behavioural issues that are directly related to e-payments.

Three functional levels/kinds of internet banking that are currently employed in accessing and evaluating internet banking have been identified and these are; informational, communicative and transactional (Thulani, et. al. 2009; Yibin 2003; \& Diniz 1998). Informational (websites): This has been identified as the first level of internet banking. The bank typically has the marketing information about the banks product and services on a stand-alone server. The risk is very low as informational systems typically have no path between the server and the banks internal network (Safeena et al 2010). Communicative/simple transactional (Websites). This type of internet banking allows some interaction between the banks system and the customer. The interaction is 
limited to electronic mail (e-mail), account inquiry, loan application or static file updates (name and address). It does not permit any funds transfers. Advanced Transactional (Websites): This level of internet banking allows bank customers to electronically transfer funds to/from their accounts, pay bills and conduct other banking transactions online.

Generally, literature on consumer behaviour places emphasis on risk as important dimension of consumption. Risk and its relationship with involvement are important because the two constructs play an important role as motivational and explanatory variables in consumer behaviour (Mitchel 1999; Laurent and Kapferer 1985). Consumers perceive greater risks when buying services than tangible goods. Zeithaml (1981) perceived services as riskier than products because services are intangible, non-standardized, and often sold without guarantees or warrantees. Consumers can rarely return a service to the service provider since they have already consumed it, and some services are so technical or specialized that consumers possess neither the knowledge nor the experience to evaluate whether they are satisfied, even after they have consumed the service (Zeithaml, 1981). Perceived risk in customer behaviour research is defined as any action of a consumer that may lead to unpleasant consequences (Lo'pez-Nicola's and Molina-Castillo, 2008). It is considered as the consumer's expectations of suffering loss in pursuit of a desired outcome. The role of risk assessment in the decision to adopt e-payments is increased because customers perform their transactions with no face to face contact with the supplier's personnel and no cash on hand. Customers generally want to master their own acts and know the cause and the consequences of their own actions (Chan and Lu, 2004). Despite the fact that epayments facilitate customers in doing their banking activities, they are still reluctant in adopting the new technology because they do not have full control over their own behaviours and system processes (Pikkarainen et al., 2004). Perceived risk is a multidimensional construct consisting of a number of dimensions: financial risk, performance risk, physical risk, social risk and psychological risk. Financial risk represents the financial loss in using e-payments, as consumers may perceive that reversing transaction, stopping a payment after discovering a mistake, or a refund may not be possible. Performance risk in e-payment cannot be used to complete a transaction when needed due to the denial of access to their account. Physical risk refers to potential injury when personal information is accessed by a third party. Social risk refers to the older generation who may disapprove of the use of e-payments due to their perception that non-electronic banking is personal and friendly. Psychological risk represents consumer perceptions that the use of electronic banking would lower their selfimage, or have a negative effect on their perceived image from other consumers. Time risk implies that it takes more time to complete a banking transaction than a non-electronic banking transaction.

By using e-payments, customers are concerned about potential financial risks such as the loss of their money during the transaction process and perceived threats for privacy and personal information leakage (Yiu et al., 2007). The perceived risk about e-banking use can be considered to involve the customers' concerns about the system's safety/security in information and money transmission and the system trustworthiness in handling customer information and managing customer's financial assets (Lee et al., 2005). Therefore, the issues of security and perceived risks are important factors in e-payments adoption In a study on customer involvement and interaction in retail banking, Howcroft et. al. (2007) findings show that lack of transparency in the sales literature and the frequent use of jargon and specialized financial terms make it difficult to make informed purchase decisions. Uncertainty can be mitigated by talking to different providers prior to a purchase and by customer deliberation that is, shopping around and looking at alternative offerings in terms of price, promotional material, and the track record and reputation of alternative providers (Howcroft et. al. 2007). They argue thus:

although branch closures have been facilitated, to some extent, by the interaction of internet banking, it has been suggested that the internet is not an ideal substitute for talking to somebody especially, when contemplating the purchase of more complicated financial products (Howcroft et al 2007. p.491).

They maintain that deliberation, talking to somebody, and willingness to switch are indicators of increased customer involvement. Similarly, knowledge and understanding, and uncertainty when making the purchase were taken as indicators of customer confidence to distinguish "good" from "bad" products, at the point of purchase. In all, the overriding consideration when buying financial products was customers need to deliberate and talk to providers before purchase; which is a wish to reduce the risk of buying something inappropriate by increasing customer knowledge and understanding of the products. Perceived risk/security is considered an important risk attribute that impacts on the consumers' decision-making process when buying a product or consuming some services. Electronic banking is a technology- enabled channel and consumers' perceive the use of e-payments as a risky decision because technology-services exhibit pervasive technological, unfamiliar and ambiguous stimuli (Davidow 1986). Therefore, when consumers decide to use electronic banking, they are exposed to uncertainties such as the availability, and the performance of the complementary electronic banking channels (Sarin et. al 2003). Ho and Ng (1994) \& Lockett and Littler (1997) empirically support that the use of electronic banking involves risk and suggested that consumers perceived that an 
existence of risk was present with the use of e-payments. Gan et al (2006) found a negative relationship between perceived risk factors and customers use of e-banking. But Safeena et. al. (2010) Shafeei and Mirani (2011) \& Giovanis et. al. (2012) found a positive relationship. These diverse findings confirm the diverse nature of consumer involvement. Six risk factors are employed in this study and based on the above the following hypotheses are formulated:

H1: Lower perception of psychological risk will impact on consumers' high involvement with electronic banking.

H2: Lower perception of social risk will lead to consumers' high involvement with e-banking services.

H3: High perception of time risk will lead to consumers' high involvement with e-banking services.

H4: Lower perception of quality risk will lead to consumers' high involvement with e-banking services.

H5: High perception of financial risk will lead consumers' high involvement with e-banking services.

H6: $\quad$ Lower perception of physical risk will lead consumers' high involvement with e-banking services.

Electronic banking adoption is linked with user's perception of security (Khan 2010). Security factors that affect consumers' adoption/usage of e-banking services are: authorized access, confidentiality, restriction on high -value transactions and strong commitment to security measures (Liao and Cheung 2002). For Transactions conducted through an open network which may involve sizeable money values, security-especially with regard to proper authorization and confidentiality-would tend to be that aspect of reliability which matters the most (Roboff and Charles 1998). Empirical studies show that security factors/concerns are positively related to consumers' adoption of e-banking services (Liao and Cheung 2002; Khan 2010; Giovanis et. al 2012). Given the possibility of hacking, tampering and information leakage over public network, the above security dimensions and factors were introduced to reveal how respondents perceive e-banking security measures. According to Olasanmi (2010) the increase in the use of the ICT facilities such as computers and internet in the perpetuation of criminal activities like spamming, credit card frauds, flashing, identity theft, denial-of-services, and many others have lend credence to the view that ICT is contributing to crime in the banking sector. This study follows the perspective that the perceived risk variables measure the customer's assessment of the service's lack of confidence as well as the systems' security and perceived risk levels, especially for individuals who have never used e-payments before. Based on the above, it is anticipated that expected security of operations affects customers' high involvement with e-payments.

H7: Expected security of operations will positively influence consumers' high involvement with e-banking services

\section{Methodology}

The sampling procedure adopted for this study is the quota sampling method. The choice of this sampling method is to allow for the selection of respondents from the different gender, income group, educational background and age in the sample. Quota sampling involves the selection of prospective participants according to pre-specified quotas for either demographic characteristics, specific attitudes or specific behaviours; and the purpose is to assure that pre-specified subgroups of the target population are represented on relevant sampling factor (Hair et. al. 2006). Accordingly surveys of this nature frequently use quotas that have been determined by the nature of the research objectives. Thus quota sampling was chosen in line with the objective of this research and its greatest advantage is that the sample generated contains specific subgroups in the proportions desired. Data used in this study came from two main sources: secondary data which were sourced from already existing materials mostly journals, government publication/bulletins, among others. On the other hand primary data were first-hand information and the instrument used for this is questionnaire designed in line and in accordance with the pattern used in the research on consumer involvement with e- banking services. Perceived risks used in this research were measured as follows: psychological risk has one item, social risk has one item, time-loss risk has three items, quality risk, physical risk and financial risk has one item each; while security has five items. These were measured with their various items using five point Likert scale: strongly agree to agree, to undecided to disagree and strongly disagree. Respondents were asked to indicate the frequency with which they use the e-payments. This is the dependent variable and is measured using frequencytype question: very often, often, occasionally, rarely and never; and this is the dependent variable, which was dichotomised to align with the chosen method of analysis. Discriminant analysis techniques are used to classify respondents into one of two or more alternatives groups or population on the basis of a set of measurements (Aakar et. al. 2005). Thus, this technique was employed to classify bank customers on the basis of high and low involvement with e-payments; and to identify which perceived risk/security items contribute to making this classifications. The questions were pre-coded for ease of analysis. The data analysis was done with the aid of IBM SPSS Statistics 20 software. 


\section{Data Analysis}

A total of 908 copies of questionnaire were returned and analysed (Table 1).

Table 1: Questionnaire Distribution and Collection.

\begin{tabular}{|l|l|l|l|l|l|l|}
\hline Zones & State & Town & No. Distributed & Percentage & No. Returned & Percentage \\
\hline Southeast & Enugu & Enugu & 183 & 16.64 & 177 & 16.09 \\
\hline Southsouth & Rivers & PortHarcourt & 184 & 16.73 & 144 & 13.09 \\
\hline Southwest & Lagos & Lagos & 183 & 16.64 & 176 & 16.00 \\
\hline Northcentral & Benue & Makurdi & 183 & 16.64 & 16.72 & 151 \\
\hline Northeast & Bauchi & Bauchi & 184 & 16.63 & 87 & 13.73 \\
\hline & FCT & Abuja & 183 & 100 & 908 & 7.91 \\
\hline Total & & 1100 & & 82.55 \\
\hline
\end{tabular}

The mean and standard deviation of the demographic variables are: gender: 1.39 and 0.488 ; monthly income: 1.81 and 0.624 ; age: 1.32 and 0.539 ; and education: 2.93 and 0.562 respectively (Table 2).

Table 2: Demographic Characteristics of Respondents

\begin{tabular}{|c|c|c|c|c|}
\hline & & Frequency & Valid Percent & Cumulative Percent \\
\hline $\begin{array}{l}\text { Gender: } \\
\text { Total }\end{array}$ & $\begin{array}{l}\text { Male } \\
\text { Female }\end{array}$ & $\begin{array}{l}550 \\
354 \\
904\end{array}$ & $\begin{array}{l}60.8 \\
39.2 \\
100.0 \\
\end{array}$ & $\begin{array}{l}60.8 \\
100.0\end{array}$ \\
\hline $\begin{array}{l}\text { Income: } \\
\text { Total }\end{array}$ & $\begin{array}{l}\text { Below N15,000.00 } \\
\$ 15,000.00-\mathrm{-} 450,000.00 \\
\$ 451,000.00 \text { and above }\end{array}$ & $\begin{array}{l}264 \\
487 \\
99 \\
850 \\
\end{array}$ & $\begin{array}{l}31.1 \\
57.3 \\
11.6 \\
100.0\end{array}$ & $\begin{array}{l}31.1 \\
88.4 \\
100.0\end{array}$ \\
\hline $\begin{array}{l}\text { Age: } \\
\text { Total }\end{array}$ & $\begin{array}{l}12-35 \text { years } \\
36-55 \text { years } \\
56 \text { years and above }\end{array}$ & $\begin{array}{l}646 \\
230 \\
27 \\
903 \\
\end{array}$ & $\begin{array}{l}71.5 \\
25.5 \\
3.0 \\
100.0\end{array}$ & $\begin{array}{l}71.5 \\
97.0 \\
100.0\end{array}$ \\
\hline $\begin{array}{l}\text { Education: } \\
\text { Total }\end{array}$ & $\begin{array}{l}\text { Primary/non-formal } \\
\text { Secondary } \\
\text { HND/BSc } \\
\text { Postgraduate }\end{array}$ & \begin{tabular}{|l|}
8 \\
144 \\
636 \\
99 \\
887 \\
\end{tabular} & $\begin{array}{l}9 \\
16.2 \\
71.7 \\
11.1 \\
100.0 \\
\end{array}$ & $\begin{array}{l}9 \\
17.1 \\
88.8 \\
100.0\end{array}$ \\
\hline
\end{tabular}

Source: Survey Data

From this age has the highest variation followed by income. ATM/debit/credit cards is the most preferred with a total of 541 responses, telephone/GSM banking has 140 responses, master/visa cards has 72, internet banking has 58, while 72 responses indicated others like western union. In terms of involvement with the services, ATM ranks first, telephone/GSM banking second, master/visa cards third. In terms of low involvement ATM is first and this attributed to the large number of respondents indicating it. Other unclassified hi-tech services is second, telephone/GSM banking is third, master/visa card is forth while internet banking is fifth (Table 3).

\begin{tabular}{|ll|c|c|c|}
\hline \multicolumn{2}{l|}{ Table 3: E-banking products * Involvement Cross Tabulation } \\
\cline { 3 - 5 } Count & \multicolumn{2}{|c|}{ Involvement } & Total \\
\hline e-banking products & ATM/debit/credit cards & low involvement & high involvement & 541 \\
& Telephone/GSM banking & 209 & 332 & 140 \\
& Internet banking & 57 & 83 & 58 \\
& Master/visa card & 17 & 41 & 86 \\
Total & Others & 23 & 63 & 72 \\
\hline
\end{tabular}

The mean and standard deviation of the items/variables are: physical risk 4.09 and .918 ; social risk: 2.84 and 1.221; quality risk: 3.59 and 1.016; financial risk: 3.87 and .971 ; time risk $1: 3.87$ and 1.026; time risk 2: 4.04 and .975; time risk 3: 3.64 and 1.013; security 1: 3.36 and 1.144; item 2: 3.75 and .829; item 3: 3.64 and 1.035; item 4: 3.88 and .888; and item $5: 3.70$ and .829 . Majority of the items have standard deviations above one and these show variations in the opinion of respondents with respect to the variables influencing involvement in epayments.

Pearson correlation was used for validity analysis to test correlation between variables and shows strong positive correlation between most of the variables; as the correlations are significant at .01 except for physical/social risk which are within acceptable confidence level. This reflects respondents general agreement with the variables included in the study.

Correlations 
Perceived Risk/Security and Consumer Involvement with Electronic Payments in Nigeria: A

\begin{tabular}{|l|l|l|l|l|l|l|l|}
\hline & $\begin{array}{l}\text { Psychological } \\
\text { risk }\end{array}$ & Social risk & $\begin{array}{l}\text { Time-loss } \\
\text { risk }\end{array}$ & Quality risk & Financial risk & Physical risk & Security \\
\hline $\begin{array}{l}\text { Psychological risk } \\
\text { Social risk }\end{array}$ & $1.298^{* *}$ & 1 & & & & & \\
Time-loss risk & $.305^{* *}$ & $.287^{* *}$ & 1 & & & & \\
Quality risk & $.295^{* *}$ & $.234^{* *}$ & $.380^{* *}$ & 1 & & & \\
Financial risk & $.231^{* *}$ & $.313^{* *}$ & $.468^{* *}$ & $.322^{* *}$ & 1 & 1 \\
Physical risk & $.089^{* *}$ & .020 & $.339^{* *}$ & $.193^{* *}$ & $.400^{* *}$ & 1 \\
Security & $.303^{* *}$ & $.420^{* *}$ & $.423^{* *}$ & $.254^{* *}$ & $.305^{* *}$ & $.309^{* *}$ & 1 \\
\hline
\end{tabular}

**. Correlation is significant at the 0.01 level (2-tailed).

Durbin Watson (DW) statistics was used to test autocorrelation and the value for all variables is 1.531 . The closer the value of DW is to 2 , the more the evidence is in favour of no autocorrelation (Gujarati 2006). Thus the DW value falls within limits and exhibit no problem of auto correlation. Cronbach Alpha statistics was used to test the reliability of the variables. Time-loss risk has a coefficient of .687 while security has .723. All the 13 items has .828 all of which are above the .6 thresh hold and merit further analysis (Table 4$)$.

Table 4: Results of Reliability Analysis

\begin{tabular}{|l|l|l|}
\hline \multicolumn{2}{|l|}{ Table 4: Results of Reliability Analysis } \\
\hline All Variables & Number of Items & Cronbach Alpha \\
\hline Psychological risk & 13 & .828 \\
\hline Social risk & 1 & NA \\
\hline Time-loss risk & 1 & NA \\
\hline Quality risk & 3 & .687 \\
\hline Financial risk & 1 & NA \\
\hline Physical risk & 1 & NA \\
\hline Security & 1 & NA \\
\hline
\end{tabular}

Discriminant Analysis was used to test the hypotheses (appendix 1). The first item is the classification of results which indicate that $65.3 \%$ of grouped cases were correctly classified. Assuming maximum chance criterion the probability of correct classification is .556 or $55.6 \%$. Also the proportional chance criterion value taken the prior probabilities of high and low involvement is $.444^{2}+.556^{2}=.506$ or $50.6 \%$. The hit ratio or percentage of cases correctly classified $65.3 \%$ is higher than both hence the discriminant analysis is valid and dependable (see Aakar et. al. 2005). Wilk's Lambda has a score of .961 and Chi square score of 31.559 , all highly statistically significant at .000. Group statistics show that for all the 7 variables, the mean scores for customers in the high involvement segment are more than that of those in the low involvement. This shows that high involvement customers had more favourable attitude toward e-banking products than low involvement customers. Test of equality of group means show that five out of the seven variables are significant in classifying e-banking customers on the basis of high and low involvement. The information in the standardised canonical discriminant function coefficients shows however that time-loss risk and security are the most dominant variables.

To compute the $\mathrm{Z}$ score for the Discriminant Analysis we look at functions at group centroid. The group means/centroids based on the discriminant function for each group are .181 for high involvement and .227 for low involvement customers. Given that the two groups have unequal sizes, the cut-off score on the discriminant function for classifying customers into high or low involvement is $(439 \times-.227+350 \times .181) / 789$ $=-.046$. Thus, the cut-off is .046 , taken the absolute value. In terms of classifying customers to one of the two groups, if an item/variable has a score greater than .046 , then the item contributes to the high involvement group. If the score is below .046 then the item contributes to low involvement group. From the structure matrix table, all the seven variables have scores above the cut-off. Time-loss risk has .818, security has .764, financial risk has .486 , and psychological risk has .450 . Others are quality risk $=.367$, physical risk $=.261$, and social risk $=.229$; thus hypotheses $1-7$ are fully validated.

\section{Summary, Conclusions and Implications}

The literature on consumer behaviour generally places emphasis on risk as important dimension of the consumer decision making process/choice model. Thus risk and need as two dimensions of consumer involvement have been the focus of attention. Risk perceptions are generally regarded as being associated with unpleasant experiences that emanate from unanticipated or uncertain consequences when purchasing products (in Howcroft et al 2007). Risk and its relationship with involvement is important because the two constructs play an important role as motivational and explanatory variables in consumer behaviour (Mitchel 1999; \& Laurent and Kapferer 1985). Financial risk represents the financial loss in using electronic banking, as consumers may perceive that reversing transaction, stopping a payment after discovering a mistake, or a refund may not be possible. Physical risk in electronic banking refers to potential injury when personal information is accessed by a third party. Social risk refers to the older generation who may disapprove of the use of electronic 
banking due to their perception that non-electronic banking is personal and friendly. Psychological risk represents consumer perceptions that the use of electronic banking would lower their self-image, or have a negative effect on their perceived image from other consumers. Time risk in electronic banking implies that it may take less time to complete a banking transaction than a non-electronic banking transaction. Security factors that affect consumers' adoption/usage of e-banking services are: authorized access, confidentiality, restriction on high -value transactions and strong commitment to security measures (Liao and Cheung 2002). In an aggregative analysis Gan et al (2006) found a negative relationship between perceived risk factors and customers use of electronic banking. But Safeena et.al. (2010) found a positive relationship. Giovanis et. al. (2012) found positive relationship between privacy risk/security and online banking adoption. This study established that six perceived risk factors and security are significant in classifying e-payments consumers on the basis of high and low involvement. This research has presented an insight into the perceived risk/security as an important variable that enhance consumer involvement with e-banking services. High consumer involvement is related to low perception of risk and security of operations.

The rapid increase in number of automated delivery channels and customers' preference to use them because of multifaceted attributes are placing pressure on banks to respond aggressively to meet the customers' needs. This study provides necessary input to bank management to increase customers' involvement through lowering risk; and enhancing security of operations. This aspect should be augmented and integrated with other aspects of the service quality of banks for satisfaction of customers.

Despite extensive use of ATMs, the absence of direct interaction with bank staff has increased customers' apprehensions about the perceived risk/security. To reduce the customers concerns about perceived risk as well as of security and privacy concerns, banks should improve the quality of interaction with the customers to alleviate these apprehensions with a view to reducing risk and enhancing security. The results of this study show that ATM usage is highest among the e-banking services. To reduce risk, ATM service should be able to provide enhanced interactivity, diversified offerings, and facilitate customers to participate in improving the service encounter with ATM and make it a memorable and pleasant experience. Banks should develop strategies to motivate low involvement customers through awareness, education, extending personalized services, and demonstrating the functions of e-baking services. This is more so as the study has shown that consumer involvement is highest among ATM users, meaning that while others e-banking products are still in the fringe ATM has graduated to mainstream. A recent report in The Economist Magazine attests to this that of all the financial innovations of the past two decades none is like ATM (The Economist 2012).

Security of operations is another dimension in the perceived risk for this study. There is no doubt that the possibilities and consequences of cybercrime threaten the survival of corporate organisations and even individuals. The growth of ICT infrastructure and the Nigeria's economy at large is at risk which is why the fears in some quarters that Nigeria will be subject to various vulnerabilities, especially cybercrimes, as the nation deploys ICT infrastructure to support her development. There is the need for the CBN, the Economic and Financial Crimes Commission (EFCC) and the Nigerian Information Technology Development Agency (NITDA) to work together toward enhancing the security of e-payments. This also calls for concerted efforts on Bio-metric ATM cards that will enhance security of e-payments.

The results of this study show that ATM still dominates the high technology payment segment of the payments market in Nigeria. Others like the internet and telephone/GSM banking are still very low. To enhance the telephone/GSM banking, there is need for mobile number portability as this service is still at it's infancy in Nigeria at present. There are about 12 million active accounts in Nigeria today. There are about 90 million mobile telephone subscriptions. This makes Nigeria a very huge market for mobile money/telephone/GSM banking. The proposed cashless policy of the CBN is probably one policy that would require a sustained media campaign as well as moral persuasion; hence there is need for sustained awareness at the grassroots. One obvious implication of the study is that banks need to identify e-banking customers on the basis of high or low involvement and motivate them accordingly. The banks should also identify their e-services on the basis of high and low involvement and take the necessary steps to address issues with those on low involvement; so as to scale up these services to the level of the ATM that now accounts for about $90 \%$ of e-payments in the country. If banks wish to enhance their competitive advantage in the financial industry, they will have to build their information technology, and in particular, their network technology in order to increase involvement of the ecustomers with the new circumstances.

\section{References}

[1]. Aaker, D.A; Kumar, V; and Day, G.S. (2005). Marketing Research. New Delhi: John Wiley \& Sons.

[2]. Achumba, I.C. (2006). The Dynamics of Consumer Behaviour. Lagos: Mc-Williams Publishers.

[3]. Aldlaigan, A.H. and Buttle, F.A. (2001). "Consumer Involvement in Financial Services: An Empirical Test of Two Measures", International Journal of Bank Marketing, $\quad$ Vol $19 \quad$ No $\quad 6, \quad$ pp $232-245$. Arnould, E; Price, L; \& Zinkhan, G. (2004). Consumers. Irvin: Mc Graw Hill.

[4]. Berkman, H.W; Lindquist, J.D. \& Sirgy, M.J. (1997). Consumer. Chicago: NTC Books.

[5]. Central Bank of Nigeria (CBN 2012). Financial Stability Report (FSR). Online Edition. 
[6]. Central Bank of Nigeria (CBN 2011). Questions and Answers on the new cashless policy. Online document. Downloaded from www.cbnonline.com.

[7]. Central Bank of Nigeria (CBN 2011). Annual Report and Statement of Accounts.

[8]. Central Bank of Nigeria (CBN) (2003). Guidelines on Electronic Banking in Nigeria August, 2003.

[9]. Chan, S. and Lu, M. 2004, "Understanding internet banking adoption and use behaviour: A

[10]. Hong Kong Perspective", Journal of Global Information Management, 12 (3), 21-43.

[11]. Davidow, W. H. (1986). Marketing High Technology: An Insider's Review. The Free Press, New York, New York.

[12]. Diniz, E. (1998). "Web Banking in USA". Journal of Internet Banking and Commerce, Vol. 3, No. 2.

[13]. Gan C; Clemes, M; Limsombunchai V; and Weng A (2006). A Logit Analysis of Electronic Banking in New Zealand. Discussion paper No. 108.

[14]. Giovanis, A.N., Biniris, S. and Polychronopoulos, G. (2012). “An extension of TAM model with IDT and security/privacy risk in the adoption of internet banking services in Greece." EuroMed Journal of Business. Vol. 7, No. 1. Assessed from emeraldinsight.com/login. Emerald Group Publishing Limited.

[15]. Hall, B. (2003). "Is Cognitive Advertising the Right Dimension? Advertising Research. World Advertising Research Centre.

[16]. Hair, J.F; Bush, R.P. and Ortinau, D.J. (2006). Marketing Research. New York: McGraw Hill/Irwin.

[17]. Ho, S. S. M., and Ng, V. T. F. (1994) “Customers' risk perceptions of electronic payment system.", The International Journal of Bank marketing. 12(8), pp.26-39.

[18]. Howcroft, B; Hamilton, R; and Hewer, P. (2007) "Customer involvement and interaction in retail banking: an examination of risk and confidence in the purchase of financial products" Journal of services Marketing: 21/7 481-491 Emerald Publishing www.emeraldinsight.com/0887-6045.htm.

[19]. Hynes, N. and Lo, S. (2005). "Innovativeness and consumer involvement in the Chinese market" Singapore Management Review. The Free Library.

[20]. Khan, M.A (2010). "An empirical study of automated teller machine service quality and customer satisfaction in Pakistani Bank s". European Journal of Social Sciences - vol. 13,No.3.

[21]. Knox S; Walker, D. and Marshall, C. (1994). "Measurement consumer with grocery brands: model validation and scale reliability test procedures", Journal of Marketing Management, Vol 10, pp 137-152. Krugman, H.E.; (1965). "The Impact of Television Advertising: Learning without Involvement", Public Opinion Quarterly, Vol 29, Autumn, pp 349-356. Laurent, G. and Kapferer, J. (1985). "Measuring consumer involvement profiles.” Journal of Marketing Research. Vol. 22, No.2: 41-53.

[22]. Lawson, R. W. (2001). “Consumer Behaviour” in Baker, M. (ed.) The IEBM Encyclopaedia of Marketing. London: Thompson Learning.

[23]. Lee E.J.; Kwon, K.N.; \& Schumann, D.W. (2005). "Segmenting the non -adopter category in the diffusion of internet banking", The International Journal of bank Marketing (23:4/5), p. 414

[24]. Liao, Z: and Cheung, M.T. (2002). "Internet based e-banking and Consumer Attitudes: An Empirical Study". Information \& Management 39: 283-295.

[25]. Lockett, A., and Littler, D. (1997) “The Adoption of Direct Banking Services”. Journal of Marketing Management. No. 13, pp. 791-811.

[26]. Lo'pez-Nicola's, C. and Molina-Castillo, F.J. (2008), "Customer knowledge management and ecommerce: the role of customer perceived risk”. International Journal of Information Management, Vol. 28 No. 2, pp. 102-13.

[27]. Mitchell, V. W. (1999). "Consumer perceived risk: conceptualizations and models", European Journal of Marketing, Vol. 33, No. $1 / 2$, Pp. 163-95.

[28]. Olasanmi, O.O. (2010). “Computer crimes and counter measures in the Nigerian Banking Sector". Journal of Internet Banking and commerce vol. 15 , No.1 April.

[29]. Peter, J.P. and Olson, J.C. (2002). Consumer Behaviour and Marketing Strategy, 6th ed., McGrawHill/Irwin. Petty R.E.; Cacioppo, J.T. and Schumann, D (1983). "Central and Peripheral Routes to Advertising Effectiveness: The Moderating Role of Involvement", Journal of Consumer Research, Vol 10, September, pp 135-146. Pikkarainen, T., Pikkarainen, K., Karjaluoto, H. and Pahnila, S. (2004), "Consumer acceptance of online banking: an extension of the technology acceptance model", Internet Research, Vol. 14 No. 3, pp. 224-35.

[30]. Ratchford, B. (2001). "The Economics of Consumer Knowledge". Journal of Consumer Research, March: $397-411$

[31]. Ray, M.L. (1973). "Marketing Communication and Hierarchy of Effects", in Sage Annual Reviews in Communication Research, Gerald Kline, F. and Clark, P. (eds.) Beverly Hills, CA: Sage Publications. Robertson T.S. (1976). "Low-commitment Consumer Behaviour", Journal of Advertising Research, Vol 16 No 2, April, pp 19-24.

[32]. Roboff, G. and Charles, C. (1998). "Privacy of Financial Information in Cyberspace: Banks addressing what consumers want". Journal of Retailing Banking Services. 20 (3). 51-56.

[33]. Safeena, R; Date, H; and Kammani, A. (2011). Internet Banking in an Emerging Economy: Indian Consumers' Perspective. International Arab Journal of e-Technology, vol. 2, No. 1.

[34]. Salehi, M. and Alipour, M. (2010). "E-Banking in emerging economy: empirical evidence of Iran" International Journal of Economics and Finance. Vol. 2, No. 1. www.ccsenet.org/ijef.

[35]. Sarin, S., Sego, T., and Chanvarasuth, N. (2003) "Strategic Use of Bundling for Reducing Consumers' Perceived Risk Associated with the Purchase of New High-Tech Products", Journal of Marketing Theory and Practice. 11(3), pp. 71-83.

[36]. Shafeei, R. and Mirani, V. (2011). "Designing a model for analysing the effect of risks on e-banking adoption by customers: a focus on developing countries” African Journal of Business Management Vol. 5 No. 15.

[37]. Sherif, M. \& Cantril, H. (1947). The Psychology of Ego-involvement: Social Attitudes and identifications. New York: John Wiley and Sons.

[38]. Sherif, M. \& Hovland, C. I. (1961). Social Judgement: Assimilation and Contrast Effects in Communication and Attitude Change. New Haven: Yale University Press.

[39]. Sherif, M.; Sherif, C.W. \& Nebergall, R.E. (1965). Attitude and Attitude Change: The Social Judgement-Involvement Approach. London: W.B. Saunders Co.

[40]. Solomon, M.R. (2005). Consumer Behaviour. New Delhi: Pearson/Prentice Hall.

[41]. The Economist (2012). "Financial Innovation: Special Report". The Economist Magazine. February $25,2012$.

[42]. Thulani, D., Tofara, C \& Langton, R. (2009). Adoption and Use of Internet Banking in Zimbabwe: An Exploratory Study. Journal of Internet Banking and Commerce, Vol. 14, No.1. 
[43]. Yibin, M.U. (2003). E-Banking: Status, Trends, Challenges and Policy Issues. Paper presented at CBRC Seminar, The Development and Supervision of E-banking, Shanghai, Nov. 24-26.

[44]. Yiu, C.S., Grand, G.R. and Edgar, D. (2007), "Factors affecting the adoption of internet banking in Hong Kong - implications for the banking sector". International Journal of Information Management, Vol. 27 No. 5, pp. 336-51.

[45]. Zaichkowsky, J.L. (1985). "Measuring the Involvement Construct", Journal of Consumer Research, Vol 12, pp 341-352.

[46]. Zaltman, G. \& Wallendorf, M. (1983). Consumer Behaviour: Basic Findings and Managerial Implications. New York: John Wiley and Sons.

[47]. Zeithaml, V.A. (1981), "How Consumer Evaluation Process Differ Between Goods and Services", in

[48]. Donnelly, J. H., and George, W, R. (Eds.), Marketing of Service, Proceedings Series of the American Marketing Association.

Appendix 1: Discriminant analysis output.

\begin{tabular}{|c|c|c|c|c|c|}
\hline \multirow[t]{2}{*}{ Involvement } & & \multirow[t]{2}{*}{ Mean } & \multirow[t]{2}{*}{ Std. Deviation } & \multicolumn{2}{|c|}{ Valid N (listwise) } \\
\hline & & & & Unweighted & Weighted \\
\hline \multirow{7}{*}{ low involvement } & psychological risk & 3.0828571 & .85745867 & 350 & 350.000 \\
\hline & social risk & 2.7628571 & 1.28838446 & 350 & 350.000 \\
\hline & quality risk & 3.5571429 & .94604764 & 350 & 350.000 \\
\hline & financial risk & 3.7800000 & .92414291 & 350 & 350.000 \\
\hline & physical risk & 4.0571429 & .85454648 & 350 & 350.000 \\
\hline & time-loss risk & -.1679800 & .98570904 & 350 & 350.000 \\
\hline & Security & -.1566335 & 1.08392406 & 350 & 350.000 \\
\hline \multirow{7}{*}{ high involvement } & psychological risk & 3.2482916 & .93625141 & 439 & 439.000 \\
\hline & social risk & 2.8769932 & 1.16978477 & 439 & 439.000 \\
\hline & quality risk & 3.7038724 & 1.00626283 & 439 & 439.000 \\
\hline & financial risk & 3.9658314 & .94902915 & 439 & 439.000 \\
\hline & physical risk & 4.1548975 & .96687957 & 439 & 439.000 \\
\hline & time-loss risk & 1615532 & .99153904 & 439 & 439.000 \\
\hline & Security & .1536725 & .92140521 & 439 & 439.000 \\
\hline \multirow{7}{*}{ Total } & psychological risk & 3.1749049 & .90533046 & 789 & 789.000 \\
\hline & social risk & 2.8263625 & 1.22433638 & 789 & 789.000 \\
\hline & quality risk & 3.6387833 & .98210720 & 789 & 789.000 \\
\hline & financial risk & 3.8833967 & .94201998 & 789 & 789.000 \\
\hline & physical risk & 4.1115336 & .91946315 & 789 & 789.000 \\
\hline & time-loss risk & .0153724 & 1.00181497 & 789 & 789.000 \\
\hline & Security & .0160209 & 1.00799163 & 789 & 789.000 \\
\hline
\end{tabular}

Tests of Equality of Group Means

\begin{tabular}{|c|c|c|c|c|c|}
\hline & Wilks' Lambda & F & df1 & df2 & Sig. \\
\hline psychological risk & .992 & 6.548 & 1 & 787 & .011 \\
social risk & .998 & 1.694 & 1 & 787 & .193 \\
quality risk & .994 & 4.365 & 1 & 787 & .037 \\
financial risk & .990 & 7.642 & 1 & 787 & .006 \\
physical risk & .997 & 2.205 & 1 & 787 & .138 \\
time-loss risk & .973 & 21.622 & 1 & 787 & .000 \\
Security & .977 & 18.874 & 1 & 787 & .000 \\
\hline
\end{tabular}

Analysis 1

Summary of Canonical Discriminant Functions

\begin{tabular}{|c|c|c|c|c|}
\hline \multicolumn{5}{|c|}{ Eigenvalues } \\
\hline Function & Eigenvalue & $\%$ of Variance & Cumulative \% & Canonical Correlation \\
\hline 1 & $.041^{\mathrm{a}}$ & \begin{tabular}{l|l|} 
& 100.0 \\
\end{tabular} & \begin{tabular}{l|l|} 
& 100.0 \\
\end{tabular} & 199 \\
\hline \multicolumn{5}{|c|}{ a. First 1 canonical discriminant functions were used in the analysis. } \\
\hline \multicolumn{5}{|c|}{ Wilks' Lambda } \\
\hline \multicolumn{2}{|c|}{ Test of Function(s) } & Wilks' Lambda & Chi-square & Sig. \\
\hline \multicolumn{2}{|c|}{1} & .961 & 31.559 & .000 \\
\hline
\end{tabular}

Standardized Canonical Discriminant

Function Coefficients

\begin{tabular}{|l|l|}
\hline & Function \\
\cline { 2 - 2 } & 1 \\
\hline psychological risk & .180 \\
social risk & -.332 \\
quality risk & .010 \\
financial risk & .153 \\
\hline
\end{tabular}


Structure Matrix

\begin{tabular}{|l|l|} 
Physical risk & -.222 \\
time-loss risk & .611 \\
Security & .622 \\
\hline
\end{tabular}

\begin{tabular}{|l|l|}
\hline & Function \\
\cline { 2 - 3 } & 1 \\
\hline time-loss risk & 818 \\
Security & 764 \\
financial risk & 486 \\
psychological risk & .450 \\
quality risk & 367 \\
physical risk & .261 \\
social risk & .229 \\
\hline
\end{tabular}

Pooled within-groups correlations between

discriminating variables and standardized

canonical discriminant functions

Variables ordered by absolute size of correlation within function.

Functions at Group Centroids

\begin{tabular}{|l|l|}
\hline Involvement & Function \\
\cline { 2 - 2 } & 1 \\
\hline $\begin{array}{l}\text { low involvement } \\
\text { high involvement }\end{array}$ & -.227 \\
\hline
\end{tabular}

Unstandardized canonical discriminant functions

evaluated at group means

Classification Statistics

Prior Probabilities for Groups

\begin{tabular}{|l|l|l|l|}
\hline Involvement & Prior & \multicolumn{2}{|l|}{ Cases Used in Analysis } \\
\cline { 3 - 4 } & & Unweighted & Weighted \\
\hline low involvement & 444 & 350 & 350.000 \\
high involvement & 556 & 439 & 439.000 \\
Total & 1.000 & 789 & 789.000 \\
\hline
\end{tabular}

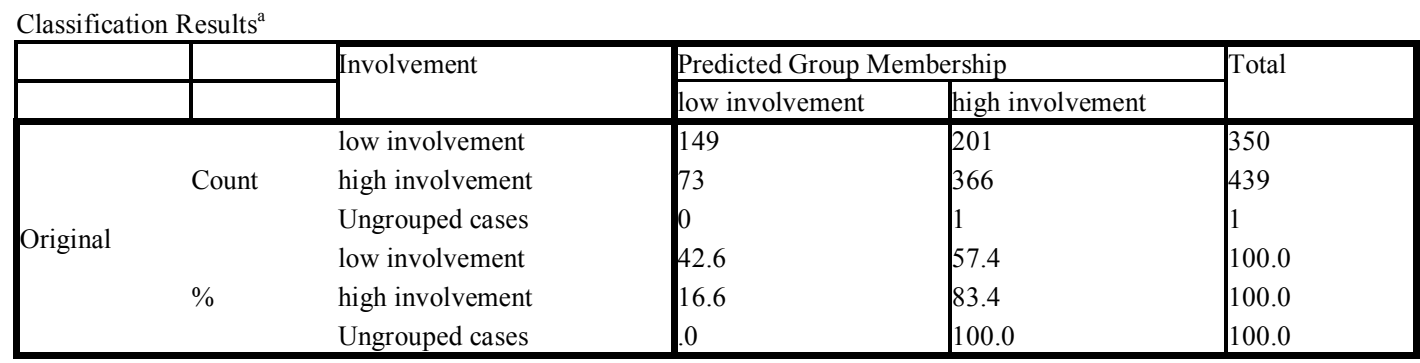

a. $65.3 \%$ of original grouped cases correctly classified. 